\title{
AUDIT SYARIAH SEBAGAI PERMASALAHAN ATAU SOLUSI UNTUK PERKEMBANGAN LEMBAGA KEUANGAN SYARIAH YANG TERDAMPAK COVID-19
}

\author{
Sophia Andini ${ }^{*}$, Paulus Sugito ${ }^{2}$ \\ ${ }^{1,2}$ Akuntansi, Fakultas Bisnis dan Komunikasi, Institut Teknologi dan Bisnis Kalbis \\ Jl. Pulomas Selatan Kav No. 22, Jakarta Timur, Indonesia 13210 \\ Email korespondensi:*sophia.andini@gmail.com
}

\begin{abstract}
This study aims to determine the factors affecting sharia audit on sharia Financial Institution. These factors include auditor competencies, process audit and Sharia framework. This study used population of external auditor on Public Accounting Firm that having audit sharia financial Institution on Covid-19 situation. In addition, this study analyzed the impact of independent variables to practice of audit sharia as dependent variable using regression analysis. Sampling was carried out in this study using purposive sampling method, which is a sampling method based on the answer of questioner respondence to external auditor audited Sharia Financial Institution. This study states that the auditor competencies and audit process have no effect to the audit sharia, other than Sharia Framework that has effect to it on Covid-19 situation.
\end{abstract}

Keywords: Sharia audit, auditor competencies, audit process, sharia framework, covid-19

\section{Research Paper \\ Management}

Received: 28 Oct 2021

Accepted: 24

Nov 2021

Online: 31

Des 2021

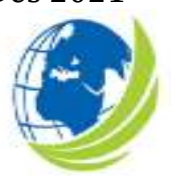

(C) The Author(s) 2021

DOI: $10.36407 /$ jmsab.v4i2.446

Jurnal

Manajemen

Strategi dan

Aplikasi

Bisnis,

Vol 4, No. 2,

2021,

pp. 562 - 571

eISSN 2655-

237X

\section{(c) (1)}

CC BY: This license allows reusers to distribute, remix, adapt, and build upon the material in any medium or format, so long as attribution is given to the creator. The license allows for commercial use. 


\section{PENDAHULUAN}

Perekenomian Indonesia tahun 2020 ini dibuka dengan kondisi yang tidak baik karena adanya pandemik. Kondisi sebuah epidemi yang menyebar dan menyerang banyak orang. Keadaan ini tidak hanya dialami oleh Indonesia, namun seluruh dunia juga sedang berduka. Beberapa aspek ekonomi dihantam hingga butuh pemulihan yang berkelanjutan. Dijelaskan oleh Sri Mulyani Indrawati selaku Menteri Keuangan serta mantan Direktur Pelaksana Bank Dunia dalam wawancaranya dengan Kompas bahwa pertumbuhan ekonomi Indonesia akan mengalami kontraksi sehingga tidak menutup kemungkinan Indonesia akan mengalami resesi ekonomi (Kompas, 2020)

Salah satu solusi dari pemulihan ekonomi yaitu pembangunan sistem ekonomi syariah yang mampu mengangkat derajat para pelaku sektor keuangan. Walaupun mengalami penurunan namun pergerakan laporan keuangan syariah masih dianggap relatif stabil dibandingkan dengan sektor konvensional. Ekonomi Syariah pernah membuktikan posisinya sebagai institusi keuangan yang tahan krisis dibanding institusi konvensional ketika terjadi krisis keuangan global pada tahun 2008 (Detik, 2020). Saat ini, penurunan terjadi di segala aspek perbankan Syariah maupun konvensional, namun kebutuhan atas audit terhadap lembaga keuangan tersebut semakin meningkat. Masyarakat membutuhkan kepercayaan yang tinggi untuk dapat menyimpan dana / asset mereka bahkan mendapatkan kredit di perbankan. Sehingga audit Syariah khususnya diharapkan mampu berevolusi mengikuti perkembangan jaman dengan berbagai kondisi yang berbeda.

Permasalahan yang ada pada sektor audit Syariah terkait dengan sumber daya manusia. Tidak semua auditor yang mengaudit LKS memiliki kompetensi dibidang Akuntansi dan bidang Syariah secara bersama-sama, normalnya akan lemah pada salah satu bidang. Padahal auditor eksternal merupakan komponen penting dalam menjaga dan memastikan integritas lembaga keuangan Syariah dalam menjalankan prinsip Syariah (Kompasiana, 2020). Penelitian yang dilakukan oleh Dewi \& Sawarjuwono (2019, p. 25) menjelaskan auditor syariah dituntut untuk memiliki kompetensi di bidang akuntansi dan audit Syariah dengan mengambil sertifikasi SAS walaupun materi USAS hanya membahas masalah teknik Akuntansi Syariah dan tidak mendetail kepada prosesnya. Pertimbangan professional juga dibutuhkan karena kondisi covid-19 ini mengalami beberapa perubahan seperti penurunanan nilai piutang murabahah (www.iaiglobal.com).

Peran sebagai auditor dalam melakukan sebuah audit bergantung pada proses audit dalam audit Syariah apakah sudah sesuai dengan kerangka Syariah dan dipatuhi oleh Dewan Pengawas Syariah. Penurunan kualitas audit pada LKS memberikan dampak yang signifikan terhadap LKS di Indonesia dimana akan memberikan tambahan proses audit yang cukup panjang dari sebelumnya (Sunariya, S.H \& Itsnaini, 2020: p. 15). Terlebih lagi dimasa Pandemic covid-19 yang menciderai dunia ekonomi secara luas, Indonesia secara khususnya, yang mengharuskan auditor untuk memaknai proses audit tersebut dengan lebih cermat dengan memperhatikan pengakuan-pengakuan untuk penyesuaian terhadap laporan keuangan yang dikeluarkan oleh Lembaga Keuangan Syariah.

Proses audit yang dilakukan harus berdasarkan professional judgement dimana hal tersebut tidak luput dari peran dan tanggung jawab dari regulasi dari pemerintah yang aktif sehingga fungsi audit dapat berjalan dengan semestinya. Kerangka audit Syariah harus menjelaskan hal tersebut sehingga memudahkan proses audit yang akan dijalankan. Hal ini disampaikan dalam penelitian yang dilakukan oleh Yasoa', Abdullah \& Endut (2020, p. 449) di Malaysia menerangkan bahwa peran auditor Syariah dibawah yuridiksi sebagai pihak ketiga untuk memberikan jaminan kepada pemangku kepentingan bahwa semua bisnis dan operasi mematuhi prinsip Syariah yang berlaku. Regulasi tersebut yang akhirnya diturunkan menjadi sebuah kerangka Syariah yang akan dijalankan oleh Auditor sebagai panduan dalam melaksanakan proses audit yang akan dijalankan. 


\section{KAJIAN PUSTAKA}

Landasan teori merupakan bagian yang penting dalam sebuah penelitian. Manfaat landasan teori adalah agar penelitian dapat tepat sasaran dan efektif. Landasan teori dalam penelitian adalah: teori legitimasi, teori agensi, audit syariah, kompetensi auditor, proses audit dan kerangka Syariah.

\section{Teori Legitimasi}

Teori legitimasi menjelaskan bahwa organisasi melakukan kegiatan operasionalnya sesuai dengan batasan dan norma-norma yang ada di masyakarat (Deegan, 2002). Teori ini menjelaskan berfokus kepada segala hubungan yang berkaitan dengan hubungan social masyarakat. System pengelolaan perusahaan yang lebih menekankan pada orientasi keberpihakan terhadap masyarat, pemerintah, individu dan kelompok masyarakat (Gray, Owen, \& Adams, 1996) memberikan penjelasan yang cukup kuat sebagai dasar dari audit Syariah.

Teori legitimasi dijadikan dasar sebagai dasar untuk semua hipotesis bahwa penugasan audit Syariah memiliki tujuan untuk khalayak ramai. Audit secara konvensional wajib memberikan pertanggung jawaban kepada stakeholder begitu pula dengan audit Syariah yang lebih mengedepankan tujuan kemaslahatan masyarakat.

\section{Teori Agensi}

Jensen dan Meckling (1976: p.354) mendefinisikan hubungan agensi sebagai suatu kontrak di bawah satu atau lebih principle yang melibatkan agent untuk melaksanakan beberapa layanan bagi mereka dengan melakukan pendelegasian wewenang pengambilan keputusan kepada agent, dengan kata lain agent disewa oleh pihak principle untuk melaksanakan suatu jasa dimana principle memberikan kuasa atau wewenang untuk membuat keputusan kepada agent yang ditunjuk tersebut.

Teori agensi dijadikan dasar hipotesis pertama bahwa kompetensi yang dimiliki seorang auditor akan berpengaruh terhadap pekerjaan yang dilakukan terhadap Lembaga Keuangan Syariah (LKS). Kompetensi tersebut akan berpengaruh terhadap laporan audit yang dihasilkan. Hal tersebut didukung oleh pernyataan Nuha (2017: p.76) yang menyatakan bahwa tugas yang diemban oleh seorang auditor konvensional maupun Syariah adalah sama dimana mereka berkewajiban memberikan jaminan bahwa laporan keuangan telah sesuai dengan standar yang diharuskan, dan memberikan jaminan bahwa memang sudah sesuai dengan prinsip yang telah dikeluarkan oleh DPS (Dewan Pengawas Syariah).

\section{Auditor Syariah}

Istilah auditor syariah digunakan untuk menyesuaikan dengan operasional entitas syariah karena proses audit dilakukan tidak hanya sesuai dengan standar regulasi tetapi juga sesuai dengan prinsip syariah (Mardian, 2013: p.89). Di Indonesia, masih belum ada auditor syariah yang fungsinya sama seperti auditor independen di lembaga konvensional (Izzatika \& Lubis, 2016: p.66), sehingga dinyatakan oleh Haniffa (2010: p.121) bahwa pemain kunci atau key player dalam audit syariah adalah Dewan Pengawas Syariah (DPS) dan auditor internal serta auditor eksternal.

DPS memiliki fungsi untuk merumuskan kebijakan dan pedoman yang harus diikuti oleh manajemen dalam melakukan kegiatan bisnis serta memberikan persetujuan atas produk yang akan dikeluarkan dan melakukan penilaian syariah, sementara auditor internaldapat menjalankan fungsi audit syariah yang bertujuan untuk memastikan bahwa pengendalian internal telah berjalan dengan baik dan sesuai dengan prinsip syariah (Yaacob, 2012: p.47). Auditor eksternal yang memiliki peran bukan hanya sebagai pemeriksa laporan keuangan, melainkan juga harus melakukan uji kepatuhan syariah untuk memastikan bahwa kegiatan yang dilakukan LKS telah sesuai dengan prinsip Syariah.

\section{Proses Audit}

Proses audit merupakan suatu prosedur yang dilakukan oleh auditor dalam kaitannya memeriksa laporan keuangan sebuah perusahaan. Auditor akan memeriksa dan menyatakan pendapat apabila laporan keuangan tersaji dengan wajar dan sesuai deng Prinsip Akuntansi berlaku umum. Proses audit yang dijelaskan dalam penelitian Akbar, Mardian, Anwar, 2015; 
p. 144) menjelaskan poin penting dalam proses audit yang dilakukan pada penelitian yaitu:

1. DPS belum dilengkapi dengan prosedur audit syariah

2. Ex- ante dan ex-pose audit belom maksimal

3. Terpisahnya audit keuangan dan audit syariah

\section{Kerangka Syariah dan Hipotesis}

Corporate Governance merupakan konsep yang diajukan demi peningkatan kinerja perusahaan melalui supervisi atau monitoring kinerja manajemen dan menjamin akuntabilitas manajemen terhadap stakeholder dengan mendasarkan pada kerangka peraturan. Pelaksanaan shariah governance pada industri perbankan Syariah harus berlandaskan kepada enam prinsip dasar. Hal yang perlu diperhatikan terkait kerangka Syariah ketika melakukan audit Syariah yaitu (Antonio, 2001)

1. Pengungkapan kewajaran penyajian laporan keuangan dan unsur kepatuhan Syariah

2. Memeriksa akuntansi dalam aspek produk, baik sumber dana ataupun pembiayaan

3. Pemeriksaan distribusi profit

4. Pengakuan pendapatan cash basis secara riil

5. Pengakuan beban secara accrual basisi

6. Dalam hubungannya dengan bank koresponden depositori, pengakuan pendapatan bagi hasil

7. Pemeriksaan atas sumber dan penggunaan zakat

8. Ada tidaknyanya transaksi yang mengandung unsur-unsur yang tidak sesuai syariah

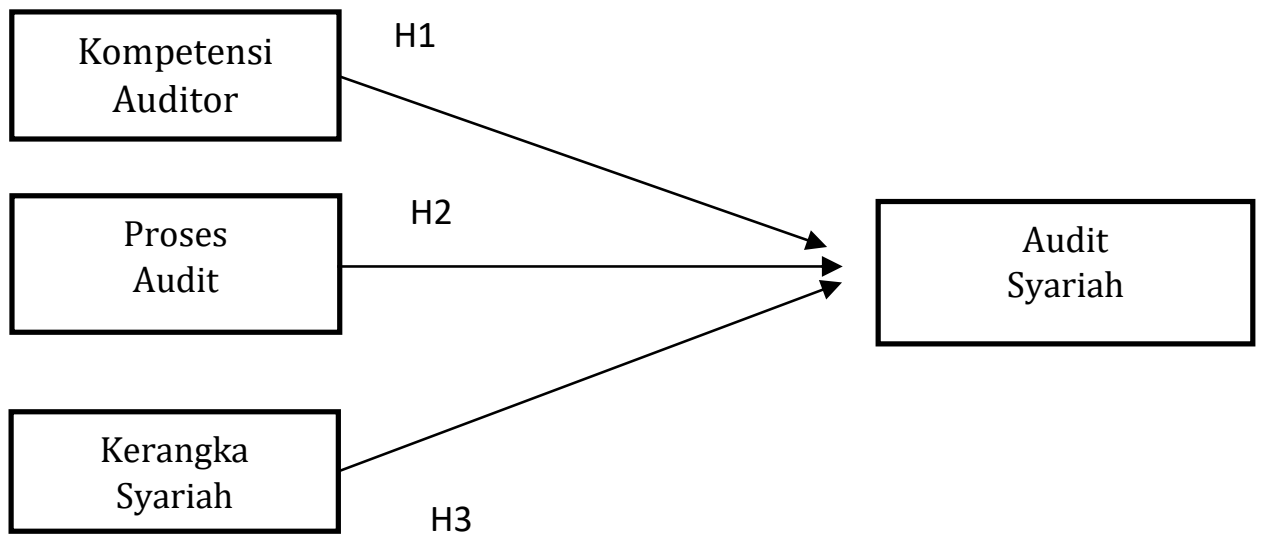

\section{Gambar 1.}

Kerangka Model Penelitian

Adapun hipotesis dari peneitian ini adalah:

H1. Kompetensi auditor berhubungan positif dengan audit syariah

H2. Proses audit berhubungan positif dengan audit syariah

H3. Kerangka syariah berhubungan positif dengan audit syariah

\section{METODE}

\section{Desain Penelitian}

Objek penelitian yang digunakan oleh peneliti yaitu kompetensi auditor, proses audit dan kerangka Syariah. Jenis penelitian yang digunakan adalah penelitian kuantitatif. Unit analisis yang dipakai adalah auditor eksternal yang sedang mengaudit Lembaga Keuangan Syariah (LKS) pada masa covid-19.

\section{Populasi dan Sampel}

Penelitian ini menggunakan populasi Kantor Akuntan Publik aktif yang terdaftar di BPK-RI yang sedang / telah mengaudit LKS. Pengambilan sampel dalam penelitian ini dilakukan 
dengan menggunakan metode purposive sampling. Sampel dalam penelitian ini yaitu auditor independent yang bekerja di KAP yang memiliki klien / mengaudit Lembaga Keuangan Syariah dengan perkiraan minimal $30 \mathrm{KAP}$ yang memenuhi kriteria sample.

\section{HASIL DAN PEMBAHASAN}

\section{Hasil Analisis Regresi Linier Berganda}

Model yang dihasilkan dari pengujian table 9 yaitu:

$Y=\alpha+\beta 1 X 1+\beta 2 X 2+\beta 3 X 3+\varepsilon \ldots$

$\mathrm{AS}=3.700-0.042 \mathrm{KA}-0.067 \mathrm{PA}+0.417 \mathrm{PA}+\varepsilon$

Persamaan Audit Syariah mengandung nilai:

1. Nilai konstanta sebesar 3.700 dimana jika nilai kompetensi auditor, proses audit dan kerangka syariah sama dengan nol, maka nilai audit Syariah adalah 3.700

2. Koefiesien regresi pada kompetensi auditor bernilai -0.042 mempunyai hubungan negatif pada audit Syariah dimana ketika kompetensi auditor bertambah, maka audit Syariah akan mengalami penurunan sebesar 0.042 dengan asumsi variable bebas lainnya konstan

3. Koefiesien regresi pada proses audit bernilai -0.067 mempunyai hubungan negatif pada audit Syariah dimana ketika proses audit bertambah, maka audit Syariah akan mengalami penurunan sebesar 0.067 dengan asumsi variable bebas lainnya konstan

4. Koefiesien regresi pada kerangka Syariah bernilai 0.417 mempunyai hubungan positif pada audit Syariah dimana ketika kerangka syariah bertambah, maka audit Syariah akan mengalami peningkatan sebesar 0.417 dengan asumsi variable bebas lainnya konstan.

\section{Tabel 1}

Analisis Regresi Linier Berganda

\begin{tabular}{|c|c|c|c|}
\hline \multirow[t]{2}{*}{ Model } & \multicolumn{2}{|c|}{$\begin{array}{l}\text { Unstandardized } \\
\text { Coefficient }\end{array}$} & \multirow{2}{*}{$\begin{array}{l}\text { Standarized } \\
\text { Coefficient } \\
\text { Beta }\end{array}$} \\
\hline & B & Std Error & \\
\hline Constant & 3.700 & 1.0794 & \\
\hline Kompetensi Auditor & -0.042 & 0.039 & 0.137 \\
\hline Proses Audit & -0.067 & 0.095 & -0.116 \\
\hline Kerangka Syariah & 0.417 & 0.067 & 1.026 \\
\hline
\end{tabular}

Sumber: diolah 2021

\section{Hasil Uji Koefisien Determinasi}

Tabel 2

Hasil Uji Koefisien Determinasi

\section{Model Summary}

\begin{tabular}{lllll}
\hline Model & $\mathrm{R}$ & R Square & $\begin{array}{l}\text { Adjusted } \\
\text { Square }\end{array}$ & $\mathrm{R}$ \\
\hline 1 & $.854^{\mathrm{a}}$ & 0.730 & 0.704 & 1.454 \\
the Estimate
\end{tabular}

\section{Sumber: diolah 2021}

Pemahaman table 10 yaitu adjusted R2 / koefisien determinasi yang telah disesuaikan adalah sebesar 0.704 yang artinya sebesar $70.4 \%$ variasi audit Syariah 
dipengaruhi oleh kompetensi auditor, proses audit dan kerangka syariah. Diluar itu 29.6\% dipengaruhi oleh faktor lain yang tidak dimasukkan dalam model regresi.

\section{Hasil Uji Hipotesis}

\section{Hasil Uji Statistik t}

Berdasarkan tabel 3 yang ada dapat di interpretasikan sebagai berikut:

1. Pengujian hipotesis pertama $\left(\mathrm{H}_{1}\right)$

Hipotesis pertama menyatakan bahwa analisis pengaruh kompetensi auditor terhadap audit Syariah memperoleh nilai signifikansi sebesar 0.291 dengan nilai t hitung -1.073. nilai signifikansi $0.291>0.05$ dan T hitung $-1.073<2.03951$. $t$ table dan koefisien beta sebesar -0.042 . Hasil pengujian menunjukkan variable kompetensi auditor memiliki koefisien regresi negatif sebesar 0,042 dengan tingkat signifikansi $0,291>\alpha 0,05$. Berdasarkan hal tersebut dapat disimpulkan bahwa variable kompetensi auditor tidak berpengaruh terhadap audit Syariah atau dengan kata lain $\mathrm{H}_{0}$ diterima dan $\mathrm{H}_{1}$ ditolak

2. Pengujian hipotesis kedua $\left(\mathrm{H}_{2}\right)$

Hipotesis kedua menyatakan bahwa analisis pengaruh proses audit terhadap audit syariah memperoleh nilai signifikansi sebesar 0.482 dengn nilai t hitung -0.712 . nilai signifikansi $0.482>0.05$ dan $t$ hitung $-0.712<2.03951$. $t$ table dan koefisien beta sebesar -0.067. Hasil pengujian menunjukkan variable proses audit memiliki koefisien regresi negatif sebesar 0.067 dengan tingkat signifikansi 0,482 $>\alpha 0,05$. Berdasarkan hal tersebut dapat disimpulkan bahwa variable proses audit tidak berpengaruh terhadap audit syariah atau dengan kata lain $\mathrm{H}_{0}$ diterima dan $\mathrm{H}_{2}$ ditolak.

3. Pengujian hipotesis ketiga $\left(\mathrm{H}_{3}\right)$

Hipotesis ketiga menyatakan bahwa analisis pengaruh kerangka syariah terhadap audit syariah memperoleh nilai signifikansi sebesar 0.000 dengan nilai thitung 6.212 nilai signifikansi $0.000<0.05$ dan thitung $6.212>2.03951$. $t$ table dan koefisien beta sebesar 1.026. Hasil pengujian menunjukkan variable kerangka syariah memiliki koefisien regresi positif sebesar 1.026 dengan tingkat signifikansi 0,000 $<\alpha 0,05$. Berdasarkan hal tersebut dapat disimpulkan bahwa variable kerangka Syariah berpengaruh terhadap audit syariah atau dengan kata lain $\mathrm{H}_{0}$ ditolak dan $\mathrm{H}_{3}$ diterima

Table 3

Hasil Uji Statistikt

\begin{tabular}{|c|c|c|c|c|c|}
\hline \multirow[t]{2}{*}{ Model } & \multicolumn{2}{|c|}{$\begin{array}{l}\text { Unstandardized } \\
\text { Coefficient }\end{array}$} & \multirow{2}{*}{$\begin{array}{l}\text { Standarized } \\
\text { Coefficient } \\
\text { Beta }\end{array}$} & \multirow[t]{2}{*}{$\mathrm{T}$} & \multirow[t]{2}{*}{ Sig } \\
\hline & B & $\begin{array}{l}\text { Std } \\
\text { Error }\end{array}$ & & & \\
\hline Constant & 3.700 & 1.0794 & & 2.063 & 0.048 \\
\hline Kompetensi Auditor & -0.042 & 0.039 & 0.137 & -1.073 & 0.291 \\
\hline Proses Audit & -0.067 & 0.095 & -0.116 & -0.712 & 0.482 \\
\hline Kerangka Syariah & 0.417 & 0.067 & 1.026 & 6.212 & 0.000 \\
\hline
\end{tabular}

Sumber: Diolah 2021 
Hasil Uji Statistik F

Tabel 4

Hasil Uji Statistik F

\begin{tabular}{lllllll}
\hline ANOVA & & \multicolumn{3}{c}{ S } & & Sig. \\
\hline Model & & $\begin{array}{l}\text { Sum of } \\
\text { squares }\end{array}$ & Df & $\begin{array}{l}\text { Mean } \\
\text { Square }\end{array}$ & F & \\
\hline & Regression & 177.201 & 3 & 59.067 & 27.938 & .000 \\
\hline Residual & 65.542 & 31 & 2.114 & & \\
\hline & Total & 242.743 & 34 & & &
\end{tabular}

Sumber: Diolah 2021

\section{Pembahasan}

Kompetensi Auditor dengan Audit Syariah

Hasil penelitian menunjukkan bahwa variable kompetensi auditor memiliki koefisien regresi negatif sebesar 0,042 dengan tingkat signifikansi 0,291 $>\alpha 0,05$. Berdasarkan hal tersebut dapat disimpulkan bahwa variable kompetensi auditor yang diukur dengan sub pernyataan mutu personal, pengetahuan transaksi Syariah, pengalaman kerja serta Pendidikan tidak berpengaruh terhadap audit syariah. Penelitian ini membuktikan bahwa kompetensi auditor yang dimiliki oleh responden KAP tidak menggunakan pengetahuan dan keahliannya secara maksimal dikarenakan responden tidak memiliki sertifikat audit Syariah sehingga pemahaman ketika melaksanakan audit Syariah tidak mampu membuktikan perkembangan audit Syariah pada masa covid-19. Selain itu, kualifikasi dan mengenai audit Syariah sangat minim sehingga terjadi ketidak seimbangan antara audit Syariah dan kompetensi auditor.

Dalam pelaksanaan audit, khususnya audit Syariah tujuan yang harus dicapai adalah memastikan seluruh kegiatan tidak bertentangan dengan fatwa, aturan dan pedoman yang dikeluarkan oleh Lembaga Keuangan Syariah tersebut. Kompetensi yang dimiliki oleh para responden kurang mencukupi wawasannya terkait dengan perkembangan audit Syariah yang ada, serta terbatasnya auditor yang memiliki kualifikasi pada dua bidang yaitu audit konvensional dan audit Syariah secara Bersama-sama. Hasil penelitian ini tidak didukung oleh penelitian yang dilakukan oleh Kooskusumawardani dan Birton (2016)

\section{Proses Audit dengan Audit Syariah}

Hasil penelitian menunjukkan bahwa variable proses audit memiliki memiliki koefisien regresi negatif sebesar $-0,067$ dengan tingkat signifikansi 0,482> $\alpha$ 0,05. Berdasarkan hal tersebut dapat disimpulkan bahwa variable proses audit yang diukur dengan pernyataan yaitu transaksi pre dan post audit Syariah pada masa covid-19. Penelitian ini membuktikan bahwa masih minimnya pengetahuan audit Syariah yang dapat dilihat pada variable X1 sehingga menyebabkan proses audit Syariah tidak berjalan dengan baik dan maksimal. Selain itu, proses audit Syariah pada masa sebelum covid dan ketika masa covid-19 tidak mempengaruhi jalannya audit Syariah yang semestinya.

Alasan lain yang bisa dipahami adalah minimnya prosedur audit yang dapat diterapkan pada proses audit Syariah dikarenakan regulasinya belum berkembang secara mapan seperti pada prosedur audit konvensional sehingga pelaksanaan audit Syariah berjalan dengan kondisi yang paling minimal. Hasil penelitian ini didukung oleh penelitian yang dilakukan oleh Akbar, Mardian dan Anwar (2015)

\section{Kerangka Syariah dengan Audit Syariah}

Hasil penelitian menunjukkan bahwa variable kerangka syariah memiliki koefisien regresi sebesar 0.417 dengan tingkat signifikansi $0,000<\alpha \quad 0,05$. Berdasarkan hal tersebut dapat disimpulkan bahwa variable kerangka Syariah yang diukur dengan pernyataan mengenai kerangka syariah terhadap audit. Penelitian ini membuktikan bahwa regulasi dan peran pemerintah terhadap kerangka Syariah mampu memberikan perkembangan yang positif terhadap audit Syariah. Kerangka Syariah yang ada 
berpanduan pada standar AAOFI dan sudah dilaksanakan oleh auditor eksternal sesuai dengan mekanismenya yang ada.

Alasan lain pada variable kerangka Syariah yang mampu mempengaruhi audit syariah adalah kerangka Syariah yang ada disesuaikan dengan proses audit yang terdiri dari tiga lapis yaitu lapis pertama yaitu pengujian audit internal, lapis kedua pengujian auditor eksternal dan lapis ketiga dilakukan pengujian oleh auditor bersertifikasi Akuntansi Syariah (SAS) (Minarni, 2013; P. 38) sehingga kerangka Syariah dipastikan sudah memiliki alurnya yang mapan. Penelitian ini didukung oleh penelitian Minarni (2013)

\section{KESIMPULAN}

Dari pengujian yang telah dilakukan terhadap permasalahan yang dirumuskan dalam hipotesis penelitian sehingga menghasilkan hasil analisis dan pembahasan yaitu:

1. Kompetensi Auditor tidak berpengaruh terhadap audit Syariah dengan kesimpulan $\mathrm{H}_{1}$ ditolak. Penelitian ini membuktikan bahwa kualifikasi professional seperti SAS mampu mengangkat praktik audit Syariah dan hal tersebut tidak didapat pada responden yang mengisi kuesioner

2. Proses Audit tidak berpengaruh terhadap audit syariah dengan kesimpulan $\mathrm{H}_{2}$ ditolak. Penelitian ini membuktikan bahwa masih minimnya prosedur audit dikarenakan regulasi yang belom berkembang secara mapan.

3. Kerangka Syariah berpengaruh terhadap praktik audit syariah dengan kesimpulan $\mathrm{H}_{3}$ diterima. Penelitian ini membuktikan bahwa perkembangan kerangka Syariah sejalan dengan maraknya Lembaga keuangan Syariah yang berpedoman pada standar AAOFI.

\section{Implikasi Praktis/Teoritis}

Hasil analisis menunjukkan adanya pengaruh audit Syariah dengan implikasi manajerial:

1. Bagi LKS

Hasil ini dapat dijadikan referensi dan pertimbangan oleh LKS yang sedang diaudit oleh auditor eksternal bahwa kerangka Syariah yang mapan mampu mempengaruhi praktik audit syariah.

2. Bagi Kantor Akuntan Publik (KAP)

Hasil ini dapat dijadikan informasi bagi para akuntan publik untuk meningkatkan skill dan memiliki sertifikasi akuntansi Syariah untuk mendukung kompetensinya di bidang audit khususnya audit syariah

3. Bagi Stakeholder lainnya

Hasil penelitian ini dapat memberikan pengetahuan dan pemahaman mengenai praktik audit Syariah

\section{Keterbasan dan Saran}

Keterbatasan pada penelitian ini adalah minimnya responden yang memenuhi kriteria pada sample penelitian, sehingga diharapkan mampu untuk memperbanyak sample penelitian untuk perkembangan ilmu yang lebih baik.

Saran bagi Penelitian selanjutnya:

a. Peneliti selanjutnya sebaiknya menggunakan ukuran yang berbeda untuk variabel independen sebagai alat ukurnya.

b. Penelitian selanjutnya menambah variable independen lainnya tetapi tetap berlandaskan pada penelitian-penelitian sebelumnya

c. Penelitian selanjutnya perlu menambah sampel yang sesuai dengan spesifikasi penelitian 


\section{REFERENSI}

AAOIFI. (2010). Accounting, Auditing, and Governance Standards for Islamic Financial Institution. Manama, Bahrain: Accounting and Auditing Organization for Islamic Financial Institution.

Akbar, T., Mardian, S., \& Anwar, S. (2019). Mengurai Permasalahan Audit Syariah dengan Analytical Network Process(ANP). Jurnal Akuntansi Dan Keuangan Islam, 101-123

Antonio, M. S. (2001). Bank Syari'ah Dari Teori ke Praktek. Jakarta: Gena Insani Press bekerjasama dengan Tazkia Cendekia.

Baroroh, A. (2013). Analisis Multivariat dan Time Series dengan SPSS 21. Jakarta: PT. Elex Media Komputindo

Dewi, S. K., \& Sawarjuwono, T. (2019). Tantangan Auditor Syariah : Cukupkah Hanya dengan Sertifikasi Akuntansi Syariah ? Jurnal Dinamika Akuntansi dan Bisnis, 17-28.

Deegan, C., (2002). The Introduction: The legitimizing effect of social and environmental disclosures - a Theoretical Foundation. Accounting, Auditing \& Accountability Journal, 282-311

Ghozali, I. (2018). Aplikasi analisis multivariate dengan program spss 25. Semarang: Badan Penerbit Universitas Diponegoro

Gray, R., Owen, D., Adams, C., (1996). Accounting and Accountability: Changes and Challenges in Corporate Social and Environmental Reporting, Prentice Hall Europe

Haniffa, R. (2010). Auditing Islamic Financial Institutions. Islamic Finance: Instruments and Markets (QFinance).

Izzatika, Nadia Farhana, and Ahmad Tarmidzi Lubis. 2016. "Isu dan Tantangan Kompetensi Dewan Pengawas Syariah di Indonesia". Jurnal Akuntansi Dan Keuangan Islam 4 (2): 147-168.

Jensen,M.C.,\&Meckling,W.H.(1979).Theoryofthefirm:Managerialbehavior,agencycosts, and ownership structure. In Economics social institutions (pp. 163-231). Springer, Dordrecht

Junusi, R. (2012). Implementasi Shariah Governance serta implikasinya terhadap Reputasi dan Kepercayaan Bank Syariah. Al-Tahrir, 87-111.

Kooskusumawardani,N. \& Birton,M.NurA. 2016. Pengaruh Kompetesi dan Independensi Auditor dalam Pelaksanaan Sharia Compliance Di Lembaga Keuangan Syariah (LKS). Simposium Nasional Akuntansi XIX

Kovinna, F. dan Betri, 2013, Pengaruh Independensi, Pengalaman Kerja, Kompetensi, dan Etika Auditor Terhadap Kualitas Audit (Studi Kasus pada Kantor Akuntan Publik di kota Palembang)

Mardiyah, Q., \& Mardian, S. (2015). PRAKTIK AUDIT SYARIAH DI LEMBAGA KEUANGAN SYARIAH INDONESIA. Akuntabilitas, 01-17.

Minarni. (2013). Konsep Pengawasan, Kerangka Audit Syariah, dan Tata Kelola Lembaga Keuangan Syariah. La_Riba Jurnal Ekonomi Islam, 29-40.

Sunariya, S.H., M. J., \& Itsnaini, P. R. (2020). DAMPAK COVID-19 TERHADAP LEMBAGA KEUANGAN SYARIAH (PERBANKAN SYARIAH). Bank Syariah Jafar, 1-17.

Yaacob, H. (2012). Issues and Challenges of Shari'ah Audit in Islamic Financial Institutions: A Contemporary View. 3rd INTERNATIONAL CONFERENCE ON BUSINESS AND ECONOMIC, (pp. 2669-2679). Bandung, Indonesia.

Yasoa, M. R., Wan Abdullah, W. A., \& Endut, A. W. (2020). The Role of Shariah Auditor in Islamic Banks: The Effect of Shariah Governance Framework (SGF) 2011. International Journal of Financial Research, 443-452

(https://www.kompas.com/tren/read/2020/09/23/123000565/siap-siap-resesi-ekonomiini-dampak-dan- cara-mengatasinya-?page=all, n.d.)

(https://finance.detik.com/moneter/d-2886801/menkeu-bambang-bank-syariah-lebihtahan- menghadapi-krisis, n.d.)

(https://www.kompasiana.com/imaaceh/573e61bf63afbd5c052e1472/pentingnya-

auditor-syariah-di- perbankan-islam?page=all, n.d.)

(http://www.iaiglobal.or.id/v03/berita-kegiatan/detailberita-1248-press-release-

\%E2\%80\%93-dampak- pandemi-covid19-terhadap-penerapan-isak-102-penurunan-nilaipiutang-murabahah, n.d.) 


\section{Author Profiles}

Sophia Andini adalah seorang dosen pada program studi Akuntansi Institut Teknologi dan Bisnis Kalbis. Pengalaman selain sebagai seorang dosen yang mengampu mata kuliah audit, akuntansi Syariah serta Sistem informasi akuntasi, Peneliti juga sebagai seorang mahasiswa doktor Ilmu Akuntansi. Topik penelitian yang digeluti diantaranya audit dan audit syariah. Penulis dapat dihubungi melalui email: sophia.andini@gmail.com

Paulus Sugito adalah seorang dosen pada program studi Akuntansi Institut Teknologi dan Bisnis Kalbis. Penulis dapat dihubungi melalui email: paulus.sugito@kabis.ac.id

\section{Correspondence.}

The author in writing this scientific publication article can be contacted via email: sophia.andini@gmail.com 